\title{
OF BELIEFS AND BEYOND: INFLUENCE OF OBEAH AND MYAL IN THE SLAVE REBELLION IN MARLON JAMES' NOVEL THE BOOK OF NIGHT WOMEN
}

\section{SANGEETA. $S^{1} \&$ B. SONIA CHELLIRIAN ${ }^{2}$}

${ }^{1}$ M.Phil. Scholar, Department of English and Languages, School of Arts and Sciences, Amrita University, Kochi, Kerala, India

${ }^{2}$ Assistant Professor, Department of English and Languages, School of Arts and Sciences, Amrita University, Kochi, Kerala, India

ABSTRACT
Religion and its practices have often been causes of conflict and have led to the division of humanity into narrow
restrictive boundaries. Religion, in most cases does not seek to empower but to restrict those practising it, from exercising their
natural freedom. However in Marlon James' novel The Book of Night Women Obeah and Myal help the slave women not
only to withstand oppression and give them the courage to seek revenge, but it also acts as a force that unites the slaves to join
the revolt. The women call upon their religious beliefs and practices to not only aid and abet them but also to give them the
courage of conviction to do the undoable. This paper seeks to take a closer look at the two Afro-Creole religions- Obeah and
Myal in terms of both their place in history, as constructors of Jamaican cultural practises, and their contribution to slave
rebellions in general and the rebellion of "the night women" in particular.
KEYWORDS: Obeah, Myal, Slavery, Jamaican Slave Rebellion \& Marlon James

Received: Jul 06, 2017; Accepted: Jul 26, 2017; Published: Aug 08, 2017; Paper Id: IJELAUG201722

\section{INTRODUCTION}

Marlon James' novel "The Book of Night Women" is set in Jamaica at the end of the eighteenth century. The book describes how a group of women, who call themselves "The Night Women", plot a slave revolt against the brutalities of the plantation masters. References to Obeah and Myal are enmeshed into the narrative almost as these religious practises were enmeshed in the lives of the Jamaican slaves. The slave in charge of the house slaves at Montpelier estate was a woman named Homer who practised Myal and it was she who brought the 'night women' together. The 'night women' had the rebellious spirit of the Akan and Ashanti tribes of Africa to which their forefathers belonged. This spirit when mixed with the powers of their faith, which was almost as dark as their skin, gave them a feeling of invincibility over their masters. Being a slave on Jamaican plantation was bad enough but to be a slave woman was even worse. Obeah and Myal gave the night, women the power to fight against oppression.

"Obeah is perhaps the oldest of all Afro-Creole religions in the Caribbean. Its name is derived from the Ashanti words Obay-ifo or Obeye, meaning wizard or witch" (South). Like many of the Jamaican traditions Borah is rooted in the islands' West African ancestry. The Ashantis or the Koromantyn Africans, who originally belonged to the Gold Coast (area dominated in the present day by Ghana) first brought with them the ancient practises of Obeah, to the Caribbean islands. Since the Spanish and the French were sceptical of the Ashanti tribes' rebellious nature they mostly refrained from importing them as slaves. Hence Obeah thrived mainly in the British West Indian colonies. Obeah 
encompassed within itself folk healing methods that relied on natural herbs and a belief in magic for good and for evil. Obeah was mostly seen in the colonial and post-colonial West Indies, as an evil practise. "The wicked Art of Negroes..." was how the Act to Remedy the Evils arising from Irregular Assemblies of Slaves, defined Obeah. Obeah- men and their 'wicked art' were held responsible for a number of deaths of both blacks and whites. Obeah was outlawed in 1760 and the practise of Obeah was punishable by flogging or imprisonment, among other penalties. The positive aspects of Obeah were all, but ignored. Even the Jamaicans came to view Obeah as black magic and witchcraft for evil. The Obeah Man or Obayifo was someone to be feared. The Obeah man worked with the super natural. He found solutions for supernatural problems and also found supernatural solutions to worldly problems

"Myal is a variation of Obeah that is practiced in Jamaica. Myal is often considered white magic as opposed to Obeah or Voodoo" (South). The Myal man carried out holiday services and also reversed harm done by the Obeah man. The Africans distinguished between practices which used sorcery, usually for evil purposes (Obeah), and those used for healing and to counteract evil (Myal). Even the masters saw that the two classes were not identical. Former Jamaican Prime Minister Edward Seaga was a practitioner of Myal. According to Seaga, Myal was created in Jamaica by African slaves, from a mixture of African religions, cultures and languages. Myalism was distinguished from Obeah. Myal was seen as a religion proper and Obeah merely as a religious practise. Joseph J. Williams, a Jesuit missionary and anthropologist, in his 1932 volume, "Voodoos and Obeahs", also describes Myal as a positive or "white" power as opposed to Obeah which was considered negative. Be that as it may be Obeah and Myal often provided "a comfort to displaced Africans in that they could rely on one of their own for healing and protection" (South).

Obeah and Myal helped the enslaved to believe that they could resist the supremacy of their masters. In stark contrast to India where the British used religious differences to rule and exploit, the Jamaican plantation slaves were united by religion. The spiritual power of Obeah and Myal was credible to the Europeans and many even resorted to Obeah at times. Even when they did not use it themselves the plantation masters were vary of the effects of Obeah and this made it a powerful tool for the slaves who wielded it to combat the worldly power of the whites. The Jamaican plantation rebellions were not brought about by the 'white man's education' which instilled in the slaves the desire to be free. The intolerable working conditions, the brutalities meted out for the slightest of slips and an inherent urge that calls out for freedom resulted in the rebellions. It was however the power of Obeah and Myal which spearheaded these rebellions, subduing their fears, easing their pain and transforming the slaves into warriors.

\section{JAMAICAN SLAVE REBELLIONS}

Nanny of the Maroons, who is a Jamaican national hero, was an Obeah woman. Not much is available as recorded history of Nanny. Some say that she was an African royalty who was captured by the British. Other accounts say that Nanny herself was an escaped slave who had been shipped from Western Africa. It has been widely accepted that she came from the Ashanti tribe of present-day Ghana. The members of the Ashanti tribe were known for their rebellious nature and were ferocious fighters. They prized their freedom above all else and refused to continue as slaves. Nanny was the spiritual and military leader of the Maroons and guided them in their resistance against the British. Along with the other Maroons, she created Nanny Town, which was in the mountains away from European settlements and was so positioned that it made it 
difficult for the Europeans to attack. Spirituality was a major part of Maroon life and they incorporated it in their everyday life. Being well versed in the practices of Obeah, Nanny commanded the respect of her troops and she was able to keep the Maroons united. She is accredited with the performance of a number of miraculous feats using her knowledge of Obeah. It is said that Nanny could catch bullets. Although Nanny attacked plantations and European settlements she preferred to farm and trade peacefully with her neighbours. She also raided the plantations to free slaves working there. Thanks to her, hundreds of slaves were able to lead a free life. Understandably, the British detested Nanny and gave a vulgar twist to stories about Nanny. It was primarily because of the accounts of Edward Braithwate that Nanny was elevated to the position of National hero status in 1976. Obeah had direct or indirect connection with most slave rebellions and was outlawed by the European masters and relegated to the status of 'wicked art of the negroes'.

Jamaica was witness to a number of slave rebellions. The harsh and often inhuman conditions in which the slaves worked along with the Ashanti's unbending spirit, led to these rebellions where the struggle for freedom was also in some measure an opportunity to seek revenge. Despite the fact that the slaves overwhelmingly outnumbered the whites, they might not have had the courage for an open rebellion, had it not been for their religious beliefs. Tacky's rebellion of 1960, is a testament to the power of those beliefs. On an Easter Sunday in the year 1960, started a slave rebellion in Jamaica that would not be quelled for several months. The rebels were slaves "from the Gold Coast, newly imported, and their leader was a Coromantin man (of the Akan people) known as Tacky" (Tacky's Rebellion, 2011). Tacky was an Obeah practitioner and the other slaves rallied around him as they believed that an Obeah man could not be harmed. His knowledge in Obeah would shield him. This knowledge gave them the courage to rebel for their freedom. In his book, The History of Jamaica, Edward Long says that:

He was an old Coromantin, who, with other of his profession, had been a chief in counselling and instigating the credulous herd, to whom these priests administered a powder, which, being rubbed on their bodies, was to make them invulnerable: they persuaded them into a belief, that Tacky, their generalissimo in the woods, could not possibly be hurt by the white men, for that he caught all the bullets fired at him in his hand, and hurled them back with destruction to his foes.(p. 451)

It was only when, the British captured an Obeah man and hanged him publicly, that the rebels were disheartened and chose to give up the struggle. Tacky was eventually shot dead by a Maroon (the Maroons were treaty bound to capture and return and at times even kill the runaway slaves). Tacky's rebellion paved the way for the 'Act to Remedy the Evils arising from Irregular Assemblies of Slaves' which made Obeah illegal and those found guilty of practicing the same were to be punished by flogging, transportation or even death. The fear impressed upon the plantation masters by Obeah and Myal made sure that only the negative connotations of these religious practices were carried forward for posterity. Even in "The Book of Night Women" Obeah is portrayed mostly as a negative force.

\section{OBEAH AND MYAL IN the Book of Night Women}

"The Book of Night Women" is the story of Lilith, born into slavery on a Jamaican sugar plantation. Lilith is invested with a dark power which was evident to the slave women around her, even at her birth. Lilith gradually recognizes this power, and (like the other slave women) comes to both revere and fear it. Circumstances lead Lilith to be a part of a clandestine 
sisterhood, which is planning a revolt that would both avenge their atrocities at the same time, ensure their freedom. Every woman in the sisterhood is invested with the dark power but Lilith's power seems to be the 'darkest' of all. Even when they doubt Lilith's integrity, the 'night women' think that Lilith will play a major role in their plans' fruition. However an Irish overseer at the plantation falls in love with her and she finds her heart responding favourably. She is torn between the 'dark' power that propels her to revolt and the love that seems to hold her back.

The colour of the white man's skin gives the weakest of his tribe, a power, quite unmatched by the strongest of the Negroes. But even the white master is terrified "of the fingers that sprinkle something in the soup that might be pepper today, poison tomorrow."(James, 2009). The slaves also know that Obeah and Myal are mysteries that the white man's knowledge has not been able to explain. The unknown breeds fear. This knowledge when combined with their own faith in their beliefs makes the slaves believe that with Homer as their leader, they are sure to escape the drudgery of slavery. The fact that she is house slave (more privileged than, and hence hated by, the field slaves) and a woman at that is all but forgotten. In their article Obeah: Healing and Protection in West Indian Slave Life, Kenneth Bilby and Jerome Handler point out that in many parts of the Caribbean the supernatural/spiritual force (or forces) that the obeah practitioner attempted to control or guide was essentially neutral, but was largely directed toward what the slave community defined as socially beneficial goals. The force could even be directed against slave masters, which, from the perspective of many enslaved persons, was a beneficial goal. It is this perspective of the slaves in the Montpelier and neighbouring estates that lets them put their complete faith in Homer. Their faith in Homer is almost as blind as their faith in Obeah and Myal. She had planned who, what, where and how the rebellion was to start but is clueless about the end. Lilith is the only person who sees that this violence for violence is not going to lead them anywhere and says as much to Homer. "'Cause everybody listen to you. All of them want to get free so bad them don't even see that you not making no sense" (James, p. 349).

The Negroes in Jamaica far outnumbered the whites. The Book of Night Women puts the ratio to be around thirty-three to one. The slaves are strong- strong enough to grab three stalk of cane in one grip and chop it straight through with one swing, strong enough to kick down a cow. If they choose to rebel, there is nothing much their masters can do about it. Hence Jamaica has had a number of slave rebellions. However it is striking that a majority of these rebellions had Obeah men or women at the helm of affairs. The belief system that can bring together- highly spirited men and women, ill-treated and illiterate-to rebel for their freedom cannot be dismissed as merely a 'dark art' as the colonial masters were prone to do. Even as the 1781 Jamaican slave law came down heavily on Obeah and its practioners, it seems to indirectly outline its positive aspects when it says that, "the weak and superstitious are deluded into a belief of their [the Obeah practitioners] having full power to exempt them whilst under their protection, from any evils that might otherwise happen.” Miguel Lorne, an attorney-at-law as well as a Rastafarian, in a newspaper article clarifies that these laws came about from the colonial masters and these laws were intended to suppress the African race and to suppress the spirituality that is within the African. Anything that the colonial master could not understand, he called it obeah and witchcraft.

Obeah and Myal were brought out in the narrative, almost as a spiritual existence rather than a religious practise. Almost as if not everyone can practise Obeah or Myal but only a chosen few who like Lilith seem to be ordained at birth. Hence a person who practises Obeah or Myal is seen as someone powerful almost to the extent of being superhuman. This 
superhuman quality makes even a slave woman like Homer powerful enough to lead a rebellion not only at her estate but bring members of other estates also to follow her lead. A woman leader is something that most men would sneer at, whether black or white but the power of Obeah and Myal seem to almost negate the perceived weaknesses of gender. However this power that drives the night women is described as a dark power. Even though Homer practises Myal, which is considered to oppose the negative effects of Obeah, it has almost the same points of origin as that of Obeah. Jamaicans (both white and black) approach both Myal and Obeah, with a mix of fear and trepidation. "But both Myal and Obeah deal with so much darkness that even nigger from the Africa sometimes don't know which is which" (James, p. 117). As such Homer was revered by the others around her and if she was ever trifled with- there were consequences. Homer uses her prowess with Myal, to conduct meetings of the group, to plan and plot, without being apprehended by the masters. The 'night women' were guided by the moon to tell them of the right time to hold a meeting. Homer was especially adept at brewing different kinds of tea that would cure a number of different maladies. She could even cure people with mental illness.

Lilith on the other hand does not actively practise Obeah or Myal but is invested with the dark powers of both. The Ashanti blood of her mother, which did not take kindly to slavery, and her father's 'white' blood, which had never known slavery, mixes in Lilith to give her powers that are akin to that of an Obeah woman. Unfortunately Lilith seems to be invested with only the dark powers of Obeah and Myal. She is unable to heal like a Myal woman, but she is able to wreak havoc like one. The other slaves fear and revere this power in Lilith and are as afraid of her as they would be of an Obeah woman. The darkness is not hers to beckon at her freewill but takes possession of her at irregular intervals. It took possession of her when it helped her to kill the obnoxious master and mistress at Coulibre estate. However it doesn't stop there. The dark power mixed with her need for self-preservation leads her to set fire to the house killing two children in the process. "True darkness and true womanness make her want to live, make her think that goddamn, this nigger goin' live longer than what white man say. Than what God say" (James, p. 229). The 'night women' are amazed at how Lilith not only manages to kill white folk in their homes but more importantly is able to get away with it. It is to be remembered that, this happened at a time when a slave woman could be whipped mercilessly, for something as trivial as serving cold tea. The 'night women' however do not see this dark power as bad, just as they do not think their dark skin makes them inferior to the white skinned masters. They respect Lilith's abilities and think she would play an important role in the rebellion. However Lilith is not sure that she wants to exercise this power.

Violence as an answer to violence does not make her feel good. She has to live with the consequences of her actions and that makes her life miserable. The dark powers that govern her tell her what to do but do not tell her how to deal with the consequences of her actions. The 'night women' are bound by the common thread of being subjects of the plantation masters' atrocities and by the fact that all except Homer are fathered by the white overseer Jack Wilkins. However Lilith is the only one who had actually killed anyone. The others had used Obeah or Myal to kill people but that was not the same. Even though, her own admission felt good to kill those who deserved to die but that feeling was short lived and what remained was a permanent weight on her conscience that could not be shaken off. She tries to warn Homer but her concerns are dismissed as the result of her growing intimacy with the Irish overseer. When the rebellion does get underway the 'night women' kill and massacre while Lilith uses her dark power to protect the only two white men who had shown her kindness at some point or the other-her father Jack Wilkins and her lover Robert Quinn. Ignoring the fact that the former had brutally raped her mother and had been the cause of her mother's death and the later had ordered her to be whipped on more than one occasion. In doing so Lilith is the 
only one of the night women who is able to achieve freedom-at least in the true sense of the word. What is true of Obeah and Myal is true for all religious beliefs. Beliefs empower individuals but how an individual uses that empowerment is entirely his or her discretion.

Even though rebellions such as the one that broke out in Montpelier estate hardly ever achieved their desired goal of freedom, and were more often than not easily quelled by the colonial masters, it gave the slaves on the Jamaican plantations, a sense of purpose. It made them see the light at the end of the tunnel without which their life would have been an endless journey through darkness. The slave rebellion led by Homer ended in casualties on both sides and the plantation masters eventually gaining control. The rebellion might seem a failure but not for Homer. The rebellion gave her death-which is after all was the ultimate freedom and Myal helped her to seek revenge. Myal did not give her freedom because it does not give you what you say you want but what your heart wants. Even though Homer kept telling others that she wanted freedom for the slaves, what she really wanted was to avenge her children's death and that's what Homer got.

The practice of Obeah and Myal depends on oral repetitions from one generation to the next. The spirit of the dead communicates with the living to tell them what their course of action should be. The dead also help the living to achieve their goals.

"It is and ever has been very difficult to extract from an old Negro what his religious belief really was, but it seems probable that there was some idea that departed parents had influence with the supposed rulers of the world beyond the grave, and that prayers were offered to them in some such spirit as that of the Roman Catholic who appeals to the saints in his calendar."(Gardner, p. 184).

In The Book of Night Women, the spirit of the dead comes back to help chronicle the life of the 'night women'. The book ends with the narrator revealing his identity as Lilith's son who is inspired to tell the story of the 'night women'. He is helped in this process by his own mother and by the woman in the bush, whose description is uncannily similar to that of Homer.

\section{CONCLUSIONS}

The Book of Night Women highlights the best and the worst of Obeah and Myal. Religion has more often than not, been a divider of humanity. It divides men into castes and sects. It divides man and woman, privileging the former over the latter. It is interesting to note that when religion does that, it is never branded as the 'wicked art' and banned. But Obeah and Myal, which brought people together and gave them the courage to fight for their freedom, was banned. These ancient practises healed as well as cursed. Unfortunately it is the negative aspects of Obeah and Myal that are often highlighted and are ingrained in popular perception even among the black population of the Caribbean. In his book, Voodoos and Obeahs, Joseph

J. Williams explains the phenomenon thus:

If he could not venerate the Supreme Being through the minor deities and ancestral spirits, he might at least placate the evil one, and bespeak his influence for purpose of revenge or to coerce his master to grant him something that he sought.

We find Obeah thus really becoming a form of devil worship in the Christian sense... (129) 
It now becomes imperative to discuss the positive aspects of a religion that could erase the differences of gender, unite people to fight for a just cause and also heal its people. These are qualities that not many religions that exist today can boast of. It would be wrong to ignore the healing and discuss only the curses. Obeah and Myal is part of the cultural identity of the people of Jamaica and is certainly more than just "the wicked art of the negroes".

\section{REFERENCES}

1. Tacky's Rebellion. (2011). Retrieved January 17, 2017, from Understanding Slavery: http://www.understandingslavery.com/index.php-option=com_content\&view $=$ article \&id=382\&Itemid=244.html

2. Bilby, K. M., \& Handler, J. S. (2004). Obeah: Healing and Protection in West Indian Slave Life. The Journal of Caribbean History ,38,2, $153-183$.

3. Gardner, W. J. (2005). The History of Jamaica: From Its Discovery by Christopher Columbus to the Year 1872. London: Routledge.

4. James, M. (2009). The Book of Night Women. New York: Riverhead Books.

5. Long, E. (1774). The History of Jamaica, Volume 2. Great Britain: T. Lowndes.

6. South, H. (n.d.). Obeah and Myal. Retrieved January 15, 2017, from People.vcu: http://www.people.vcu.edu/ wchan/poco/624/harris_south/Obeah\%20and\%20Myal.htm

7. Williams, J. J. (1933). Voodoos and Obeahs: Phases of West India Witchcraft. Alexandria: Library of Alexandria. 
